\section{High Tunnel Coverings Alter Crop Productivity and Microclimate of Tomato and Lettuce}

\author{
Kelly M. Gude and Eleni D. Pliakoni \\ Department of Horticulture and Natural Resources, 22201 W. Innovation \\ Drive, Kansas State University, Olathe, KS 66061
}

Brianna Cunningham, Kanwal Ayub, and Qing Kang Department of Statistics, 101 Dickens Hall, Kansas State University, 1116 Mid-Campus Drive N. Manhattan, KS 66505

Channa B. Rajashekar

Department of Horticulture and Natural Resources, 3036 Throckmorton PSC, 1712 Claflin Road, Manhattan, KS 66506

\section{Cary L. Rivard \\ Department of Horticulture and Natural Resources, Olathe Horticulture Center, 35230 W. 135th Street, Kansas State University, Olathe, KS 66061}

Additional index words. canopy/soil temperature, growing degree-days, hoophouses, photosynthetic active radiation, polyethylene (poly), season extension

Abstract. The implementation of high tunnels has shown to increase marketability and/or yield of tomato (Solanum lycopersicum) and lettuce (Lactuca sativa) crops compared with open-field systems. These structures provide the opportunity to alter light intensity and spectral quality by using specific polyethylene (poly) films and/or shadecloth, which may affect microclimate and subsequent crop productivity. However, little is known about how specific high tunnel coverings affect these parameters. The overall goal of this study was to evaluate the impact of various high tunnel coverings on the microclimate and crop productivity of tomato and lettuce. The coverings included standard, ultraviolet (UV)-stabilized poly film (standard); diffuse poly (diffuse); full-spectrum clear poly (clear); UV-A/B blocking poly (block); standard + $55 \%$ shadecloth (shade); and removal of standard poly 2 weeks before initial harvest to simulate a movable tunnel (movable). Microclimate parameters that were observed included canopy and soil temperatures, canopy growing degree-days (GDD), and photosynthetic active radiation $(P A R)$, and crop productivity included yield and net photosynthetic rate. Hybrid red 'BHN 589' tomatoes were grown during the summer, and red 'New Red Fire' and green 'Two Star' leaf lettuce were grown in both spring and fall in 2017 and 2018. Increased temperature, GDD, and $P A R$ were observed during the spring and summer compared with the fall. The soil temperatures during the summer increased more under the clear covering compared with the others. For tomato, the shade produced lower total fruit yield and net photosynthetic rate (Pn) compared with the other treatments, which were similar $(P<0.001$ and $<0.001$, respectively). The greatest yield was $7.39 \mathrm{~kg} / \mathrm{plant}$, which was produced under the clear covering. For red leaf lettuce grown in the spring, the plants under the clear, standard, and diffuse coverings had significantly greater yield than the movable and shade coverings $(P<0.001)$. The coverings had less effect on the yield during the fall lettuce trials, which may have been attributed to the decrease in $P A R$ and environmental temperatures. The findings of this study suggest that high tunnel coverings affect both microclimate and yield of lettuce and tomato.

High tunnels are often used for environmental protection, increased marketability, and an extended production season (Lamont, 2009). In contrast to greenhouses, high tunnels are less expensive to construct or maintain, as they rely on passive ventilation with a single (or double) layer of poly stretched over the top of the tunnel (Janke et al., 2017). The two most common warm- and cool-season crops grown in high tunnels in the central in the high tunnel environment. GDD is a heat index used to predict when a crop will reach maturity and may positively influence yield (McMaster and Wilhelm, 1997). This was seen in spring tomato trials in North Carolina, where high tunnels accrued more daytime heat and accumulation of GDD compared with the open field, which optimized early-season production (O'Connell et al., 2012). One of the advantages of the high tunnel system is that the grower is able to select particular shadecloth and/or poly film coverings to maximize yield or other production characteristics for their market. For example, in the study by O'Connell et al. (2012), the authors suggested using shadecloth as a way to potentially reduce fruit cracking for heirloom tomato production.

High tunnel coverings have been found to alter spectral quality, light intensity, plant growth, and phenolic compounds (Flaishman et al., 2015; Oh et al., 2011; Tsormpatsidis et al., 2008; Zhao et al., 2007). When combined with poly film, shadecloth has shown to reduce maximum soil temperature, leaf evapotranspiration, and leaf temperature during production periods with temperatures $>30^{\circ} \mathrm{C}$, which are common to the central United States (Zhao and Carey, 2009) and are detrimental to tomato growth (Saeed et al., 2007). The utilization of a $50 \%$ shade screen in a greenhouse study improved marketability by reducing the incidence of tomato blossom end rot (Lorenzo et al., 2006). However, shade has been found to reduce irradiance, $P A R$, and $\mathrm{P}_{\mathrm{n}}$ (Agati and Tattini, 2010; Li et al., 2017). PAR is the amount of light available for photosynthesis, which is between 400- and 700-nm wavelength range (Espí et al., 2006). In a high tunnel study in Serbia, a $40 \%$ black shadecloth on top of standard poly reduced tomato fruit size compared with a standard poly alone (Ilić et al., 2015).

A movable tunnel is a mobile high tunnel that can be moved along a track to continue planting new crops under the protection of the tunnel once the plants have established their root system (Jett, 2017). Movable tunnels increase the capacity for crop rotation and the inclusion of cover crops, which is why they are promoted for their ability to maintain soil health. The movable tunnel also gives growers the ability to alter the quantity of light throughout crop growth, while providing protection to multiple crops per season. However, little is known about the practical application of increasing solar light preharvest through removal of high tunnel coverings or with the use of a movable tunnel. A few studies have included preharvest full-spectrum light exposure coverings 2 to 4 weeks before harvest in growth chambers (Becker et al., 2013), greenhouses (Hipol and Dionisio-Sese, 2014), and high tunnels (Zhao et al., 2007) to study the effects of antioxidant accumulation. However, Hipol and DionisioSese (2014) sowed Red Rapids and Lollo Rosa lettuce cultivars under $80 \%$ shade and transplanted to various shaded conditions 2 weeks before harvest. They found that the leaf area 
and leaf length increased under the $0 \%$ or $30 \%$ shade compared with the $56 \%$ or $80 \%$ shade.

Standard poly used on high tunnel systems has shown to decrease $P A R$ by $23 \%$ (Bumgarner et al., 2012). In addition, standard poly has shown to reduce ultraviolet-A light by more than $60 \%$ and ultraviolet-B by $90 \%$ relative to open-field plots (Tsormpatsidis et al., 2008). However, sensitivity to ultraviolet-B can vary by crop species and cultivar (Krizek et al., 1997; Tevini and Teramura, 1989). Crop growth and elongation is regulated by the $H$-indole- 3 -acetic acid hormone, which is both absorbed and readily destroyed by ultraviolet-B (Mark and Tevini, 1996). A red leaf lettuce study grown with ultraviolet-B exclusion had $63 \%$ greater fresh weight (FW) compared with the full-spectrum control, while those grown under ultraviolet-A/B exclusion had an additional $43 \%$ greater FW compared with ultraviolet-B exclusion alone (Krizek et al., 1998). A high tunnel study with ultraviolet-B excluding poly film revealed an increase in leaf enlargement and biomass accumulation with cucumber, soybean [Glycine max (L.) Merr.], and New Zealand spinach [Tetragonia tetragonoides (Pallas) Kuntze] (Adamse et al., 1997).

To our knowledge, very few studies have examined the effect of altering solar light through the implementation of specific high tunnel coverings. Replicated studies require large, customized tunnel structures to impose the coverings in question. Therefore, the first objective of this report was to evaluate the impact of the high tunnel coverings on $P A R$ and provide relevant microclimate canopy and soil temperature, and GDD accumulation during spring, summer, and fall. The second objective was to understand the effect of high tunnel covering on crop productivity, yield, and Pn of tomato and lettuce. This study is a part of a larger study that examined the effects of high tunnel coverings on microclimate, yield and productivity, and health-promoting phytochemicals of lettuce and tomato.

\section{Materials and Methods}

Trials were conducted at the Kansas State University Olathe Horticulture Research and Extension Center (OHREC), located in Olathe, KS from 2017 to 2019. OHREC is located in Johnson County, KS (lat. $38.885357^{\circ} \mathrm{W}$ ). The soil is Chase silt loam (pH 6.5). The trial was

Received for publication 23 Aug. 2021. Accepted for publication 4 Oct. 2021

Published online 13 January 2022.

Submitted as a portion of a dissertation in fulfillment of a degree requirement. The assistance of Paul Anderson and the staff and students at K-State Olathe Horticulture Center is gratefully acknowledged. We also acknowledge the U.S. Dept. of Agriculture's National Institute of Food and Agriculture who funded this project.

C.L.R. is the corresponding author. E-mail: crivard@ksu.edu.

This is an open access article distributed under the CC BY-NC-ND license (https://creativecommons. org/licenses/by-nc-nd/4.0/). conducted in four, "caterpillar" high tunnels, which are homemade high tunnels whereby hoops are bent out of galvanized metal fencing material using a specific pipe bender (Quick Hoops Bender; Johnny's Seed, Winslow, ME). The construction of a homemade high tunnel allowed for customization to suit the needs of the experiment with regard to plot size and tunnel length. The overall design of the caterpillar tunnel is a long and narrow with low ceilings, which provides an ideal structure for an experiment that specifically examines the impact of solar light. The four high tunnels were $39.6 \mathrm{~m}$ long $\times 3.7 \mathrm{~m}$ wide $\times 2.1 \mathrm{~m}$ high with two beds that ran lengthwise in each high tunnel (39.6 m long $\times 0.61 \mathrm{~m}$ wide). The tomato trials were arranged in a randomized complete block design (RCBD) and the lettuce trials used a split-plot RCBD. Both crops were replicated four times and were blocked by each individual high tunnel. Each replication (high tunnel) had a total of six consecutive covering plots $(6.1 \mathrm{~m}$ long) that spanned the width of the tunnel (3.7 m wide) and were joined at the long end by hip boards. An additional 2.1-m buffer area was included at the ends of each tunnel as well as $1.5 \mathrm{~m}$ at either end of each plot to minimize interplot interference. Data were collected from the middle $3.1 \mathrm{~m}$ of each plot. The replicated high tunnels relied on passive ventilation without side or endwalls. But during periods of freezing temperatures $\left(<0{ }^{\circ} \mathrm{C}\right)$, sidewalls, floating rowcovers, and/or the replacement of poly over the movable covering was added.

The coverings included standard UV-stabilized poly film (standard); diffuse poly (diffuse); full-spectrum clear poly (clear); UV-A/ B blocking poly (block); standard $+55 \%$ shadecloth (shade); and removal of standard poly 2 weeks before initial harvest to simulate a movable tunnel (movable). The standard covering was rated for $92 \% P A R$ transmission and was reported to block $<350$ nm [6-mil (K-50 poly; Klerk's Plastic Product Manufacturing, Inc., Richburg, SC)]. The movable covering simulated the use of a movable tunnel, by allowing for plant establishment in a protected environment before full solar exposure occurred 2 weeks before harvest. The 2-week period was chosen because it is critical for the accumulation of health-promoting flavonoid phytochemicals; the results are discussed in Gude et al. (2020). The diffuse covering is reported to remove direct radiation of infrared (IR) light and blocks <380 nm [6-mil (Luminance; Visqueen Building Products, London, UK)]. The clear covering did not contain a UV inhibitor (6-mil Clear Plastic Sheeting; Lowes, Mooresville, NC). The block covering blocked $<400 \mathrm{~nm}$ [6-mil (Dura Film Super 4; BWI Companies, Inc., Nash, TX)]. The shade covering was a $55 \%$ shadecloth + standard poly underneath, marketed to protect crops from heat stress (Sunblocker Knitted Shade; FarmTek, Dyersville, IA).

Water was applied through drip irrigation. One drip tape ran down the length of each bed with emitters spaced every $30 \mathrm{~cm}$ and delivered $0.0019 \mathrm{~m}^{3}$ of water per $31 \mathrm{~m}$. The trial was irrigated three days per week (Monday, Wednesday, Friday) for 60 and 90 min per irrigation event during the spring/ fall and summer, respectively. Additional water was provided to the entire trial as needed during hot periods during of the summer.

Temperature and GDD. High tunnel soil and canopy temperatures $\left({ }^{\circ} \mathrm{C}\right)$ were recorded throughout the six growing seasons (three seasons/year $\times 2$ years) in the six coverings (two replications per covering). In each replication, one temperature probe (EL-USB-1; Lascar Electronics, Erie, PA) was buried 10 $\mathrm{cm}$ below the soil surface and the second was located in the plant canopy $(0.15 \mathrm{~m}$ above the soil surface for tomato, and at the soil surface for lettuce) similar to Bumgarner et al. (2011). Although the mature tomato plants exceeded the temperature probe height, the added shade from the plant canopy prevented any overheating as a result of direct sunlight. The probes were placed in the north row of the high tunnels in the center of each plot. Radiation shields were used to further protect the canopy probes from direct sunlight, and soil temperature probes were in sealed metal containers to prevent damage from soil moisture (Lascar Electronics). Temperatures were recorded every $30 \mathrm{~min}$, and results are the average of the minimum and maximum temperatures. For tomato, sensors collected temperature data from 7 July to 4 Oct. 2017 and on the same dates in 2018 ( 89 d). For fall lettuce, sensors collected temperature from 27 Oct. to 19 Nov. 2017 ( 24 d) and 25 Oct. to 13 Dec. 2018 (50 d). For spring lettuce, sensors collected temperature from 1 Apr. to 9 May 2018 and on the same dates in 2019 (39 d).

The accumulated values for GDD were determined using the standard equation from McMaster and Wilhelm (1997). The equation is GDD $=\Sigma\left(\mathrm{T}_{\text {MAX }}+\mathrm{T}_{\text {MIN }}\right) / 2-\mathrm{T}_{\text {BASE}}$, where $\mathrm{T}_{\text {MAX }}$ was the highest canopy temperature recorded during a 24-h day, $\mathrm{T}_{\mathrm{MIN}}$ was the lowest canopy temperature recorded during a 24-h day, and $\mathrm{T}_{\mathrm{BASE}}$ was set at $10^{\circ} \mathrm{C}$ for summer tomato (O'Connell et al., 2012) and $5^{\circ} \mathrm{C}$ for spring and fall lettuce (Gieske et al., 2016). The symbol $\Sigma$ denotes the sum over a set of terms.

PAR and $P_{n} \cdot$ PAR $\left(\mu \mathrm{mol} \cdot \mathrm{m}^{-2} \cdot \mathrm{s}^{-1}\right)$ and $\mathrm{P}_{\mathrm{n}}$ $\left(\mu \mathrm{mol} \cdot \mathrm{m}^{-2} \cdot \mathrm{s}^{-1}\right)$ rates were measured between 1000 and 1300 HR on cloudless days before harvest using a handheld open gas exchange system, CID-340 (CID Bio Science, Inc., Camas, WA). Three measurements of $\mathrm{P}_{\mathrm{n}}$ and $P A R$ were taken in succession per leaf per plot to represent the plot as a whole. Measurements were taken on a plant in the center of the plot in the north bed using a healthy leaf from the lower-most whirl for lettuce, and the third to fifth leaf from the main axis terminal for tomato (one that was large enough to cover the entire inner area of the $11 \mathrm{~cm}^{2}$ cuvette) (Reddy and Matcha, 2010). Only flat, open leaves in the direct sunlight with no shade from other leaves or structures were measured. The PAR measurements taken at the movable covering (without covering), were considered to be $100 \%$ solar 
transmittance, and were used to quantify the other covering's decrease in radiation (\%).

$P A R$ and $P_{n}$ measurements were taken preceding peak harvests, $\approx 2$ weeks after poly was removed over the poly removal treatment. For $P A R$, four replications were measured during summer, fall, and spring. For $\mathrm{P}_{\mathrm{n}}$, three replications were measured each measurement day in the summer tomato $(1,3$, and 5 Aug. 2018), and three replications per lettuce cultivar were measured each measurement day in the fall (5 and 9 Dec. 2018). Two replications per lettuce cultivar were measured each measurement day in the spring (30 Apr. and 5 May 2019) due to technical issues with the device. The measurements were taken during the second year of each trial because the device was not available the first year. Values provided here are means across the measurement days.

Tomato trials. Tomato trials occurred during Summer 2017 and 2018 using the hybrid cultivar BHN 589 (Johnny's Selected Seeds). Tomato plants (14 plants per plot) were grown in a single row down each raised (8 $\mathrm{cm}$ high) bed with $45-\mathrm{cm}$ in-row spacing and $1.5-\mathrm{m}$ spacing between the beds from centerto-center. Tomato seeds were planted $17 \mathrm{Apr}$. 2017 and 20 Apr. 2018 into 50-cell propagation trays (5-cm cell diameter) (50 Cell Plug Flats, Johnny's Selected Seeds) with commercial potting mix (Fafard 3B; Conrad Fafard, Agawam, MA) and grown in the greenhouse. Tomatoes were transplanted into the high tunnels on 30 May 2017 and 18 May 2018. Shadecloth was added to the plots receiving that treatment on 11 July 2017 and 9 July 2018. The removal of the poly for the movable treatment occurred 11 Aug. 2017 and 22 July 2018. Common cultural methods that were consistent with commercial high tunnel production were implemented (Buller et al., 2016). A custom-blended granular fertilizer mix [31N-16P-16K (Loveland Products, Inc., Greenville, MS)] was incorporated into the beds before planting at a rate of 112 $\mathrm{kg} \cdot \mathrm{ha}^{-1}$ nitrogen. Weeds were suppressed with plastic mulch in the beds and fabric mulch between the beds. The plants were grown using a stake and weave trellis system.

Fruit with any visible color were harvested weekly from each plot. They were graded as marketable or nonmarketable and the fruit number and weight were recorded. Nonmarketable fruit were determined based on presence of decay, mold, cracking that extended beyond the shoulder, small size (smaller than $3.8 \mathrm{~cm}$ diameter), pest damage, and other defects. At the end of each growing season, the plants were stripped of all fruit larger than $4 \mathrm{~cm}$ and weighed to determine overall crop productivity. In 2017, tomato fruit were harvested from 10 Aug. to 4 Oct. In 2018, tomato fruit were harvested from 30 July to 4 Oct. Aboveground biomass was sampled at the end of each season to determine vegetative plant growth. One plant per plot was cut $2 \mathrm{~cm}$ above the soil on 4 Oct. 2017 and 4 Oct. 2018, and dried for at least $72 \mathrm{~h}$ at $70^{\circ} \mathrm{C}$. The yield parameters that were observed included total and marketable yield
( $\mathrm{kg} / \mathrm{plant})$, total and marketable fruit size $(\mathrm{kg} /$ sample), marketability by weight (\%), and aboveground biomass (g).

Lettuce trials. Red 'New Red Fire' and green 'Two Star' lettuce (Johnny's Selected Seeds) were grown in trials that occurred during Fall 2017 and 2018 and Spring 2018 and 2019. The main plots included the coverings as described previously, and the subplots consisted of the two different leaf colored cultivars that were tested. Lettuce was seeded in the greenhouse into 72-cell propagation trays (3.8-cm diameter) (Pro-Tray 72 Cell Flats, Johnny's Selected Seeds) with potting mix. The lettuce was transplanted in a staggered double row within each bed $(26.7 \mathrm{~cm}$ between plant, $26.7 \mathrm{~cm}$ between rows) (24 plants/plot). A fertilizer mix [13N-0P-46K (Multi-K Classic; Haifa Group, Haifa, Israel)] was incorporated into the beds 2 weeks after planting at a rate of $11.2 \mathrm{~kg} \cdot \mathrm{ha}^{-1}$ nitrogen.

In the fall, lettuce was sowed into propagation trays in the greenhouse 7 Sept. 2017 and 19 Sept. 2018, and transplanted into the high tunnels 6 Oct. 2017 and 24 Oct. 2018. During fall and in contrast to spring and summer, shadecloth was used throughout the entire growing season. Poly removal occurred 2 weeks before harvest on 27 Oct. 2017 and 26 Nov. 2018. Lettuce was harvested once it reached commercial size (at least $25 \mathrm{~cm}$ ). The fall lettuce season was $\approx 4$ weeks longer in 2018 because of field flooding that delayed planting, followed by cold winter temperatures that delayed plant growth.

In all of the lettuce trials, harvesting was performed in the morning by cutting the aboveground part of the plant (all intact leaves) at the soil level using a harvesting knife (Harris Seeds, Rochester, NY). Six plants were randomly selected from each plot at each harvest to measure marketable plant FW (g/plant). In 2017, harvest took place on 10, 14, and 17 Nov. In the 2018 trial, the plants were harvested on 10, 12, and 13 Dec.

In the spring, lettuce seed was sown into propagation trays in the greenhouse on 14 Feb. 2018 and 19 Feb. 2019, and transplanted into the high tunnels 19 Mar. 2018 and 1 Apr. 2019. Shadecloth was added on 9 Apr. 2018 and 15 Apr. 2019, and the poly was removed the same days on 9 Apr. 2018 and 15 Apr. 2019. In 2018, harvest took place 6 weeks posttransplant on 3, 7, and 9 May. In 2019 , harvest took place four weeks posttransplant on 6,8, and 10 May.

If temperatures fell below $0{ }^{\circ} \mathrm{C}$, the covering on the movable covering was replaced during the nighttime until temperatures rose. In addition, floating rowcovers $\left(26 \mathrm{~g} \cdot \mathrm{m}^{-2}\right)$ were added to the beds at night when temperatures fell below $-6{ }^{\circ} \mathrm{C}$.

Statistical analysis. The summary statistics were presented for soil and canopy temperatures (average of the minimum and maximum temperatures) as well as canopy GDD. $P A R$ was analyzed to detect differences between covering and season. The tomato trials implemented an RCBD and the crop yield response parameters were analyzed under the linear mixed model with year and replication as the blocking factors. Tomato yield was analyzed to detect differences between covering and year. Random effects of the model were rep(year) (or rep nested within year), and rep(year) $\times$ covering (i.e., the error term). Tomato net photosynthetic rate was analyzed for 1 year to detect differences between covering alone.

The lettuce trials implemented a split-plot RCBD with repeated measures with year, replication, and season as the blocking factors. Lettuce marketable yield was analyzed separately between cultivars to detect differences between covering, season, covering $x$ season, and year(season). Random effects of the model were rep $\times$ year(season), and rep $\times$ covering $\times$ year(season). The variancecovariance structure of the error term was taken to be compound symmetry for harvest. Least squares means (LSMeans) and their standard errors were reported. Within a season, pairwise comparisons between two coverings were performed based on the twosided test for non-zero difference in means. Lettuce net photosynthetic rate was analyzed separately between cultivars and seasons to detect differences between covering alone. The adjustment for multiplicity was carried out using Tukey's method. All tests were conducted at the 0.05 significance level. Statistical analysis was executed via Statistical Analysis Software (SAS version 9.4; SAS, Inc., Cary, NC) PROC MIXED with option $\mathrm{DDFM}=\mathrm{KR}$ in MODEL statement.

\section{Results}

Temperature. During the spring, the highest canopy temperatures recorded were under the movable covering at $20^{\circ} \mathrm{C}$, which was $2.8^{\circ} \mathrm{C}$ greater than under the clear and shade (Table 1). The mean soil temperature was slightly warmer under the clear covering at $15.7^{\circ} \mathrm{C}$, and was $0.9^{\circ} \mathrm{C}$ greater than the shade covering. During the summer, there was less differentiation in canopy and soil temperature between coverings. In the fall, the canopy temperature was highest under the movable covering at 15.4 , which was $2.7^{\circ} \mathrm{C}$ greater than the shade. During the fall, the standard, clear, and diffuse coverings warmed the soil slightly more than the movable and shade coverings.

The GDD difference due to covering was observed within all three growing seasons (Table 2). During the spring trials, the shade resulted in the lowest GDD, which was $82.5 \%$ of the movable covering GDD. Similar to canopy and soil temperatures, there was less differentiation between coverings during the summer trials. During the fall, the diffuse, clear, and movable coverings had a higher accumulation of GDD compared with the shadecloth treatment. The plants under the shade were exposed to only $78.7 \%$ of the GDD compared with those under the diffuse. The use of shade decreased the spring and fall soil temperatures, spring and fall canopy temperatures, and spring and fall GDD more than the other coverings. 
Table 1. Canopy and soil average ${ }^{\mathrm{z}}$ temperatures $( \pm \mathrm{SD})\left({ }^{\circ} \mathrm{C}\right)^{\mathrm{y}}$ under high tunnel coverings in Olathe, $\mathrm{KS}$.

\begin{tabular}{|c|c|c|c|c|c|c|}
\hline \multirow[b]{2}{*}{ Coverings ${ }^{\mathrm{x}}$} & \multicolumn{2}{|c|}{ Spring } & \multicolumn{2}{|c|}{ Summer } & \multicolumn{2}{|c|}{ Fall } \\
\hline & Canopy & Soil & Canopy & Soil & Canopy & Soil \\
\hline Standard & $18.4 \pm 7.4$ & $15.4 \pm 4.0$ & $24.7 \pm 2.1$ & $24.6 \pm 1.7$ & $14.0 \pm 5.0$ & $11.4 \pm 3$ \\
\hline Movable & $20.0 \pm 6.3$ & $15.1 \pm 3.7$ & $25.2 \pm 2.0$ & $24.7 \pm 1.7$ & $15.4 \pm 5.0$ & $10.9 \pm 3.5$ \\
\hline Diffuse & $17.7 \pm 6.7$ & $15.5 \pm 3.9$ & $24.3 \pm 2.1$ & $24.3 \pm 1.6$ & $14.1 \pm 4.5$ & $11.7 \pm 3.3$ \\
\hline Clear & $17.2 \pm 6.0$ & $15.7 \pm 4.0$ & $24.9 \pm 2.2$ & $25.4 \pm 1.7$ & $14.6 \pm 4.7$ & $11.6 \pm 3.4$ \\
\hline Block & $17.9 \pm 6.8$ & $15.6 \pm 4.0$ & $25.2 \pm 2.2$ & $25.0 \pm 1.7$ & $14.1 \pm 4.6$ & $11.1 \pm 3.4$ \\
\hline Shade & $17.2 \pm 6.8$ & $14.8 \pm 3.6$ & $25.3 \pm 2.1$ & $24.9 \pm 1.8$ & $12.7 \pm 4.3$ & $10.9 \pm 3.6$ \\
\hline
\end{tabular}

${ }^{\mathrm{z}}$ Average of the minimum and maximum temperature.

${ }^{\mathrm{y}}$ Temperatures were recorded during two consecutive summers (2017-18), falls (2017-18), and springs (2018-19). Canopy probes were added $0.15 \mathrm{~m}$ above the soil surface for summer and at the soil surface during fall and spring, and soil temperature probes were added $10 \mathrm{~cm}$ below the soil surface. Two probes per covering recorded temperature in 30-min increments throughout each growing season.

${ }^{\mathrm{x}}$ Trial was arranged in a randomized complete block design, blocked by high tunnel, with the following six different polyethylene (poly) films randomly assigned within each tunnel: standard poly (standard), poly removal 2 weeks before harvest (movable), diffuse poly (diffuse), clear poly (clear), ultraviolet-A/B block poly (block), 55\% shadecloth on standard poly (shade).

PAR. PAR measurements under the movable covering happened in completely unobstructed sunlight, following poly removal, and the values observed in the movable treatment are expected to be the same as the open field. Overall, higher $P A R$ values were observed during the spring and summer trials as compared with the fall trials (Table 3 ). In the spring trials, $P A R$ was decreased under the diffuse and shade coverings at 1029 and 512 $\mu \mathrm{mol} \cdot \mathrm{m}^{-2} \cdot \mathrm{s}^{-1}$ compared with the movable treatment at $1578 \mu \mathrm{mol} \cdot \mathrm{m}^{-2} \cdot \mathrm{s}^{-1}$. During the summer, the movable covering was significantly higher than all other coverings at 1501 $\mu \mathrm{mol} \cdot \mathrm{m}^{-2} \cdot \mathrm{s}^{-1}$. The PAR observed in the fall was significantly lower than during the spring

Table 2. Canopy growing degree-days ${ }^{\mathrm{z}}(\mathrm{GDD} \pm$ $\mathrm{SE})$ of consecutive summer tomato and spring/fall lettuce trials years in high tunnel trials in Olathe, KS

\begin{tabular}{lllc}
\hline Coverings $^{\mathrm{y}}$ & \multicolumn{1}{c}{ Spring } & \multicolumn{1}{c}{ Summer } & Fall \\
\hline Standard & $553 \pm 8.5$ & $1246 \pm 6.2$ & $262 \pm 12.5$ \\
Movable & $578 \pm 14.1$ & $1304 \pm 7.5$ & $275 \pm 11.2$ \\
Diffuse & $499 \pm 7.1$ & $1236 \pm 5.8$ & $277 \pm 12.2$ \\
Clear & $480 \pm 7.9$ & $1241 \pm 7.1$ & $276 \pm 13.1$ \\
Block & $505 \pm 9.0$ & $1254 \pm 6.7$ & $241 \pm 11.7$ \\
Shade & $477 \pm 9.9$ & $1283 \pm 10.0$ & $218 \pm 11.0$
\end{tabular}

${ }^{\mathrm{z}}$ Temperatures were recorded in the summer from 7 July to 4 Oct. 2017 and 2018 ( 89 d), in the fall from 27 Oct. to 19 Nov. 2017 ( 24 d) and 25 Oct. to 13 Dec. 2018 (50 d), and in the spring from 1 Apr. to 9 May 2018 and 2019 (39 d). GDD had a $10^{\circ} \mathrm{C}$ base for summer tomatoes and $5{ }^{\circ} \mathrm{C}$ base for fall and spring lettuce. Canopy probes, added $0.15 \mathrm{~m}$ above the soil surface for summer and on top of the soil surface for fall and spring, recorded temperature in 30min increments throughout the growing season (two probes per covering).

${ }^{\mathrm{y}}$ Trial was arranged in a randomized complete block design, blocked by high tunnel, with the following six different polyethylene (poly) films randomly assigned within each tunnel: standard poly (standard), poly removal 2 weeks before harvest (movable), diffuse poly (diffuse), clear poly (clear), ultraviolet-A/B block poly (block), $55 \%$ shadecloth on standard poly (shade). and summer, although similar trends were observed with a decrease under the shadecloth treatment.

As compared with an open-field setting, $P A R$ transmission during the spring was as follows: $88 \%$ under the standard, $79 \%$ under the clear, $77 \%$ under the block, $65 \%$ under the diffuse, and $32 \%$ under the shade. The shade only transmitted $24 \%$ and $39 \%$ of the available $P A R$ in the summer and fall, respectively.

Tomato fruit crop productivity. The high tunnel covering had an effect on all crop productivity parameters other than aboveground biomass (Table 4). A slight effect of year was seen for total yield with $6.97 \mathrm{~kg} / \mathrm{plant}$ average in 2017 and $5.97 \mathrm{~kg} /$ plant average in 2018; however, the effect of year was not seen for the other parameters. For total yield $(\mathrm{kg} /$ plant), total fruit size ( $\mathrm{kg} /$ fruit), and $\mathrm{P}_{\mathrm{n}}$ $\left(\mu \mathrm{mol} \cdot \mathrm{m}^{-2} \cdot \mathrm{s}^{-1}\right)$, it was observed that all coverings performed similarly with the exception of the shade covering $(P<0.001,<0.001$, and $<0.001$, respectively; Table 5). Total and marketable yield increased most under the clear and diffuse coverings, although it did not differ significantly from the standard, movable, and block coverings. Interestingly, marketability was highest under the shade, which differed significantly from the movable. There were no significant differences for biomass accumulation observed under the different covering treatments.

Crop productivity of lettuce. Season strongly affected crop productivity, with greater marketable FW and net photosynthetic rate in the spring season compared with the fall for both red and green lettuces (Table 6). The high tunnel covering, season, strong effect on red leaf yield. During the spring, the green leaf lettuce yield was affected by covering $(P<0.05)$, but there were no significant pairwise comparison differences observed (Table 7). During the fall, the covering did not have a significant effect on FW yield or net photosynthetic rate of either the green or red leaf lettuce. and year nested within season, all had a
Table 3. The effect of season, covering, and their interaction on photosynthetic active radiation $\left[P A R^{\mathrm{z}}\left(\mu \mathrm{mol} \cdot \mathrm{m}^{-2} \cdot \mathrm{s}^{-1}\right)\right]$ in high tunnels in Olathe, KS.

\begin{tabular}{lcrl}
\hline Factors & Spring & Summer & Fall \\
\hline Coverings $(\mathrm{C})^{\mathrm{y}}$ & & & \\
$\quad$ Standard & $1394 \mathrm{ab}$ & $1103 \mathrm{~b}$ & $428 \mathrm{ab}$ \\
Movable & $1578 \mathrm{a}$ & $1501 \mathrm{a}$ & $523 \mathrm{a}$ \\
Diffuse & $1029 \mathrm{~b}$ & $987 \mathrm{~b}$ & $364 \mathrm{ab}$ \\
Clear & $1240 \mathrm{ab}$ & $1025 \mathrm{~b}$ & $428 \mathrm{ab}$ \\
Block & $1208 \mathrm{ab}$ & $1135 \mathrm{~b}$ & $407 \mathrm{ab}$ \\
Shade & $512 \mathrm{c}$ & $376 \mathrm{c}$ & $207 \mathrm{~b}$ \\
$P$ value & $<0.001$ & $<0.001$ & $<0.05$ \\
Season $(S) P$ value & $<0.001$ & & \\
S $\times$ C $P$ value & $<0.001$ & & \\
\hline$P A R$ Wa measured & $\mathrm{b}$ & & \\
\hline
\end{tabular}

${ }^{\mathrm{z}} P A R$ was measured before harvest on cloudless days in the spring (30 Apr. and 5 May 2019), summer (1, 3, and 5 Aug. 2018), and fall (16 Nov. and 5 Dec. 2018). Values are three measurements to represent the replication as a whole (four reps per covering). Means with same letter do not differ significantly at $P \leq 0.05$, Tukey's honestly significant difference.

${ }^{\mathrm{y}}$ The following six different polyethylene (poly) films were randomly assigned as covering: standard poly (standard), poly removal 2 weeks before harvest (movable), diffuse poly (diffuse), clear poly (clear), ultraviolet-A/B block poly (block), 55\% shadecloth on standard poly (shade).

\section{Discussion}

The goal of this study was to document the impact of various high tunnel coverings on the microclimate and crop productivity of lettuce and tomato during spring, summer, and fall. Little replicated work has been done in this area, and it is quite difficult to conduct similar studies with standard high tunnels. The tunnels used for these trials were designed for this experiment and were custom-made to be lower to the ground $(2.1 \mathrm{~m}$ tall) compared with a standard high tunnel ( 4 to $6 \mathrm{~m}$ tall). The tunnel structures provided an excellent method for conducting replicated high tunnel research focused on light. However, it is important to note that each replication was a single tunnel, and the impact of covering on temperature could have been biased by interplot interference. Careful steps were taken to reduce this occurrence, which included centrally locating data loggers and regularly ventilating the tunnels to prevent the build-up of heat unless necessary for crop survival. Future trials may consider using a scaled-down design that uses 24 small tunnels or installing "endwalls" between the plots of the existing structure.

In our trials, both covering and season affected temperature, GDD, and $P A R$ within the high tunnels. It has been documented that $P A R$ is highest from May to July and lowest in December, but shifts based on location within the United States (Wilson and Meyers, 2007). Likewise, $P A R$ was highest in the spring and lowest in the fall. Covering had a greater effect on the measured parameters in the spring and summer compared with the fall. The reduced effect of covering treatment in the fall was likely due to the reduction 
Table 4. Probability values ${ }^{\mathrm{z}}$ of the main effects of covering and year on the crop productivity of 'BHN 589' tomato grown in high tunnels in Olathe, KS, in Summer 2017 and 2018.

\begin{tabular}{lccc}
\hline Parameter & Covering $^{\mathrm{y}}$ & $\mathrm{Yr}$ & Covering $\times$ Yr \\
\hline Total yield (kg/plant) & $<0.001$ & $<0.05$ & NS \\
Total fruit size (kg/sample) & $<0.001$ & $\mathrm{NS}$ & $\mathrm{NS}$ \\
Marketable yield (kg/plant) & $<0.001$ & $\mathrm{NS}$ & $\mathrm{NS}$ \\
Marketable fruit size (kg/sample) & $<0.05$ & $\mathrm{NS}$ & $\mathrm{NS}$ \\
Marketability $(\%$ by weight) & $<0.05$ & $\mathrm{NS}$ & $\mathrm{NS}$ \\
Biomass $(\mathrm{g})$ & $\mathrm{NS}$ & $\mathrm{NS}$ & $\mathrm{NS}$ \\
Net photosynthetic rate $\left(\mu \mathrm{mol} \cdot \mathrm{m}^{-2} \cdot \mathrm{s}^{-1}\right)$ & $<0.001$ & - & - \\
\hline
\end{tabular}

${ }^{\mathrm{z}} \mathrm{A}$ linear mixed model was used to test which factors and interactions had significant effect on the examined quality parameter $(P \leq 0.05)$.

${ }^{\mathrm{y}}$ The following six different polyethylene (poly) films were randomly assigned as covering: standard poly (standard), poly removal 2 weeks before harvest (movable), diffuse poly (diffuse), clear poly (clear), ultraviolet-A/B block poly (block), 55\% shadecloth on standard poly (shade).

NS $=$ nonsignificant.

in available solar light and/or temperature (Wilson and Meyers, 2007).

The standard poly was designed to transmit high $P A R$, and the highest $P A R$ values were observed under the standard poly with $88 \%$ transmission in the spring and $83 \%$ transmission in the fall. In the summer, the transmission was $74 \%$, which is more similar to a high tunnel study in Ohio, where standard poly had spring and fall $P A R$ transmission of $77 \%$ relative to full sunlight (Bumgarner et al., 2012). In our trials, the standard poly trapped heat in the spring with higher canopy temperatures, which contributed to higher GDD accumulation in the spring, when compared with other coverings besides movable. O'Connell et al. (2012) observed that double-layer poly accrued more GDD compared with the open field in North Carolina, thus increasing the rate to maturity within the tunnel. Further studies that examine the rate of GDD accumulation in high tunnels with various coverings would be valuable for understanding how season extension can be manipulated by grower practices.

The movable covering simulated the use of a movable tunnel and also provides valuable insight for gathering microclimate data relevant to open-field conditions. Movable tunnels have recently become popular in the commercial high tunnel market; therefore, there are too few data among the literature to compare the results of this study. In this study, the canopy temperatures in the uncovered plots (movable) were higher than those in the covered plots in both the spring and fall, indicating that the covered high tunnel environment was cooler than the open field. These findings are contrary to published data from North Carolina (O'Connell et al., 2012), as well as assumptions by growers and researchers. It is important to note that this study was performed in Kansas, where regular sustained winds provide for excellent ventilation of high tunnels (Buller et al., 2016). In the Southeastern United States, low sustained daily wind and the presence of an inflated double-layer of poly film may lead to increased heat accumulation within the high tunnel (O'Connell et al., 2012). During the spring and summer, the removal of the covering resulted in higher GDD than the other tested coverings. During low outdoor temperatures in the late part of the fall $\left(<0^{\circ} \mathrm{C}\right)$, sidewalls, floating rowcovers, and/or the replacement of poly over the movable covering was added. Careful steps were taken to prevent unintended bias regarding light. However, this protocol likely altered the movable covering canopy temperatures in the fall. It is important to note that a grower would have to implement similar methods to ensure the success of the crop.

The poly film used for the clear covering degraded quickly because it was not manufactured for high tunnel use and needed to be replaced annually. But it may provide greater insight into the role of light on crop productivity and quality. Compared with the unobstructed light under the movable covering, the clear poly transmitted $61 \%$ UV-A, 65\% UV-B (Gude et al., 2020), and 78\% $P A R$ on average across the three seasons. In addition, during the spring and summer, the soil increased in temperature under the clear covering compared with the other tested coverings, which past studies suggest may be a result of the increased radiation (Miles et al., 2012). Understanding how the use of UV inhibitors on poly films affects the microclimate, yield, and quality will be important for future studies with high tunnel production systems

The block poly covering was designed with an added UV inhibitor to block $<400$ $\mathrm{nm}$ but maintain a high $P A R$ transmission rate (Krizek et al., 2006). It was found that the block poly transmitted 24\% UV-A, 6\% UV-B (Gude et al., 2020), and 79\% PAR on average across the three seasons. A UV exclusion study occurred with poly film over window boxes, one transmitted UV-A/B (similar to the current study's clear covering) and another blocked UV-A/B (Krizek et al., 1998). They observed that the UV-transmittal covering increased $P A R$ transmission by $10 \%$ compared with the block covering. Although the trial design differed from the one used in this study, we found that the PARs under the block, clear, diffuse, and standard coverings were statistically similar. Future research may consider a larger trial design that assigns one covering per high tunnel to amplify the microclimate effect of the coverings on a commercial scale.

The diffuse poly is marketed to diffuse light, reduce IR and leaf temperature, and transmit UV spectra (Oh et al., 2011). Overall, our study confirmed these claims, as the summer soil and canopy temperatures were reduced under the diffuse poly compared with the other coverings. In the fall, the diffuse poly warmed the soil temperatures, which resulted in higher fall GDD than all other tested coverings. Diffuse poly reduced $P A R$ transmission more than all coverings other than the shade in each season, transmitting $68 \% P A R$ on average across the seasons and has previously been reported to transmit just $40 \%$ to $50 \%$ PAR (Lang, 2014).

Table 5. Crop productivity of 'BHN 589' tomato grown in high tunnels in Olathe, KS, in 2017 and 2018.

\begin{tabular}{|c|c|c|c|c|c|c|c|}
\hline Covering $^{x}$ & $\begin{array}{l}\text { Total yield } \\
(\mathrm{kg} / \text { plant })^{\mathrm{z}}\end{array}$ & $\begin{array}{l}\text { Total fruit size } \\
\text { (kg/fruit) }\end{array}$ & $\begin{array}{c}\text { Marketable yield } \\
(\mathrm{kg} / \text { plant })\end{array}$ & $\begin{array}{l}\text { Marketable fruit } \\
\text { size (kg/fruit) }\end{array}$ & $\begin{array}{l}\text { Marketability } \\
\text { (\% by wt) }\end{array}$ & Biomass (g) & $\underset{\left(\mu \mathrm{mol} \cdot \mathrm{m}^{-2} \cdot \mathrm{s}^{-1}\right)^{\mathrm{y}}}{\mathrm{P}_{\mathrm{n}}}$ \\
\hline Standard & $6.53 \mathrm{a}$ & $0.18 \mathrm{a}$ & $5.21 \mathrm{a}$ & $0.19 \mathrm{ab}$ & $76.5 \mathrm{ab}$ & 310 & $20.3 \mathrm{a}$ \\
\hline Movable & $6.17 \mathrm{a}$ & $0.18 \mathrm{a}$ & $4.53 \mathrm{ab}$ & $0.18 \mathrm{ab}$ & $69.5 \mathrm{~b}$ & 248 & $24.1 \mathrm{a}$ \\
\hline Diffuse & $7.17 \mathrm{a}$ & $0.18 \mathrm{a}$ & $5.67 \mathrm{a}$ & $0.18 \mathrm{ab}$ & $73.3 \mathrm{ab}$ & 246 & $20.0 \mathrm{a}$ \\
\hline Clear & $7.39 \mathrm{a}$ & $0.19 \mathrm{a}$ & $5.62 \mathrm{a}$ & $0.19 \mathrm{a}$ & $70.6 \mathrm{ab}$ & 278 & $20.5 \mathrm{a}$ \\
\hline Block & $6.62 \mathrm{a}$ & $0.18 \mathrm{a}$ & $5.13 \mathrm{a}$ & $0.19 \mathrm{a}$ & $73.9 \mathrm{ab}$ & 311 & $21.6 \mathrm{a}$ \\
\hline Shade & $4.40 \mathrm{~b}$ & $0.15 \mathrm{~b}$ & $3.72 \mathrm{~b}$ & $0.15 \mathrm{~b}$ & $77.7 \mathrm{a}$ & 209 & $12.1 \mathrm{~b}$ \\
\hline
\end{tabular}

${ }^{\mathrm{z}}$ Fruit with any visible color was harvested weekly from each plot, graded, marked as marketable or unmarketable, and the fruit number and weight were recorded. Tomato fruit were harvested from 10 Aug. to 4 Oct. 2017 and from 30 July to 4 Oct. 2018. Aboveground biomass data taken once each year (four plants per covering measured both years).

${ }^{\mathrm{y}}$ Net photosynthetic rate $\left(\mathrm{P}_{\mathrm{n}}\right)$ was measured three times before harvest on cloudless days on 1, 3, and 5 Aug. 2018. Values are three measurements to represent the replication as a whole ( $\geq$ three reps per covering).

${ }^{\mathrm{x}}$ The following six different polyethylene (poly) film coverings were assigned within each tunnel: standard poly (standard), poly removal 2 weeks before harvest (movable), diffuse poly (diffuse), clear poly (clear), ultraviolet-A/B block poly (block), 55\% shadecloth on standard poly (shade). Parameters marked with different letters are significantly different $(P \leq 0.05)$. Tukey's honestly significant difference. 
Table 6. Probability values ${ }^{\mathrm{z}}$ of the main effect covering on the crop productivity parameters of red 'New Red Fire' and green 'Two Star' leaf lettuce grown in high tunnels in Olathe, KS, in the fall (2017-18) and spring (2018-19).

\begin{tabular}{lccccc}
\hline Parameter & Leaf color & Covering & Season & \multicolumn{1}{c}{ Yr $(\text { Season) })^{\mathrm{y}}$} & Season $\times$ Covering $^{\mathrm{x}}$ \\
\hline Fresh wt $(\mathrm{g} / \mathrm{plant})$ & Red & $<0.001$ & $<0.001$ & $<0.001$ & $<0.05$ \\
& Green & $<0.05$ & $<0.001$ & $<0.001$ & - \\
Net photosynthetic rate $\left(\mu \mathrm{mol} \cdot \mathrm{m}^{-2} \cdot \mathrm{s}^{-1}\right)$ & Red & NS & $<0.001$ & $<0$. & NS \\
& Green & NS & $<0.001$ & NS \\
\hline
\end{tabular}

${ }^{\mathrm{z}} \mathrm{A}$ linear mixed model was used to test which factors and interactions had significant effect on the examined quality parameter $(P \leq 0.05)$.

${ }^{\mathrm{y}}$ Year (season) factor is year nested within season.

${ }^{\mathrm{x}}$ The following six different polyethylene (poly) films were randomly assigned as covering: standard poly (standard), poly removal 2 weeks before harvest (movable), diffuse poly (diffuse), clear poly (clear), ultraviolet-A/B block poly (block), 55\% shadecloth on standard poly (shade).

Ns $=$ nonsignificant.

Many HT growers are currently using or interested in using shadecloth to protect their crops from the effects of high temperature and/or heat stress. Interestingly, during the summer season with the highest outdoor temperatures, the shade had high canopy temperature and high GDD relative to the other coverings other than the movable treatment. In the spring and fall, the lowest observed soil temperatures were under the shade covering, and the GDD was low relative to the other tested coverings. Across the three seasons, only $32 \%$ of $P A R$ was transmitted under the shade covering, which is similar to what others have reported (Agati and Tattini, 2010; Li et al., 2017; Zhao and Carey, 2009).

We set out to understand the effect of covering on $\mathrm{P}_{\mathrm{n}}$ and yield of tomato and lettuce in different growing seasons. Several investigators have reported positive correlation among $P A R, \mathrm{P}_{\mathrm{n}}$, and yield (Agati and Tattini, 2010; Lorenzo et al., 2006; Oh et al., 2011). It is likely that a reduction of $P A R$ caused by the use of shadecloth resulted in the reduction of $\mathrm{P}_{\mathrm{n}}$ and yield (Agati and Tattini, 2010). The summer $P A R$ and tomato $\mathrm{P}_{\mathrm{n}}$ increased under the movable covering, but the $\mathrm{P}_{\mathrm{n}}$ did not differ significantly from standard, diffuse, clear, and block covering. Because $P A R, \mathrm{P}_{\mathrm{n}}$, and yield often positively correlate, it would be expected that the yield within the movable plots would exceed the other coverings. However, total yields were similar to the other coverings, with the exception of the shadecloth. GDD is sometimes used to predict when crops will reach maturity (O'Connell et al., 2012), but higher GDD did not positively influence marketable tomato yields in these trials. The decrease in marketable yield under the movable covering was likely due to fruit cracking driven by summer rain events (O'Connell et al., 2012). Besides additional plot space, the movable tunnel offers growers the opportunity to expose the crop to the full sunlight before harvest to enhance its nutritional quality, as past greenhouse (Becker et al., 2013) and high tunnel (Zhao et al., 2007) studies have shown. Although the poly and shadecloth removal by Zhao et al. (2007) was unintentional due to severe weather, they observed the positive increase in antioxidant accumulation. Expanded research on the movable tunnel should include crop-pecific timing treatments of the tunnel move to optimize quality and productivity. It has been shown that total yield and size of hydroponic tomatoes increased with higher nutrient solution temperature because higher temperatures encourage plant growth due to a greater rate of carbon fixation, achieved by more efficient light interception (Moorby and Graves, 1979). Similarly, the clear poly increased summer soil temperatures, $P A R$, and UV radiation, as well as total yields when compared with the shade covering. It should be noted that although the use of shadecloth resulted in lower tomato yield and size compared with the other coverings, the marketability was highest of the tested coverings. This has been found in other tomato studies that evaluated the effect of shade (Lorenzo et al., 2006) and may contribute to current grower-adoption of shadecloth in growing regions like the central United States.

The implementation of high tunnel systems has been particularly important for coolseason crops like leafy greens where the growing season can be dramatically extended (Carey et al., 2009). It has been observed that location, season, leaf color, and environment alter yield and quality of cool-season crops grown in high tunnels (Borrelli et al., 2013; Bumgarner et al., 2011; Wallace et al., 2012; Zhao and Carey, 2009). The spring soil temperatures increased under the standard, diffuse, clear, and block coverings relative to the movable and shade coverings, with similar results observed for the marketable FW of both red and green lettuce. Others have reported that the yield of romaine lettuce grown in a high tunnel was positively influenced by increased soil temperatures in both spring and fall (Bumgarner et al., 2011). Decreased spring soil temperatures among the shade and movable coverings may have contributed to a decrease in yield for both the red and green lettuce tested in this report. Similarly, a previous study in Mississippi that used the same red and green cultivars as the

Table 7. Marketable yield (g/plant fresh weight) and net photosynthetic rate $\left(\mathrm{P}_{\mathrm{n}} \mu \mathrm{mol} \cdot \mathrm{m}^{-2} \cdot \mathrm{s}^{-1}\right)^{\mathrm{z}}$ of red 'New Red Fire' and green 'Two Star' leaf lettuce grown in high tunnels in Olathe, KS, in the fall (2017-18) and spring (2018-19).

\begin{tabular}{|c|c|c|c|c|c|c|c|c|}
\hline \multirow[b]{3}{*}{ Covering $^{\mathrm{y}}$} & \multicolumn{4}{|c|}{ Spring } & \multicolumn{4}{|c|}{ Fall } \\
\hline & \multicolumn{2}{|c|}{ Marketable yield } & \multicolumn{2}{|c|}{$P_{n}{ }^{x}$} & \multicolumn{2}{|c|}{ Marketable yield } & \multicolumn{2}{|c|}{$\mathrm{P}_{\mathrm{n}}$} \\
\hline & Red & Green & Red & Green & Red & Green & Red & Green \\
\hline Movable & $158 \mathrm{bc}$ & 182 & 12.1 & 23.2 & 36.8 & 52.7 & 4.2 & 4.9 \\
\hline Diffuse & $195 \mathrm{a}$ & 221 & 13.9 & 12.4 & 41.9 & 52.8 & 3.2 & 5.0 \\
\hline Clear & $201 \mathrm{a}$ & 223 & 18.6 & 21.2 & 38.7 & 49.7 & 3.4 & 4.7 \\
\hline Block & $179 \mathrm{ab}$ & 221 & 18.3 & 21.6 & 34.8 & 42.6 & 3.8 & 3.8 \\
\hline
\end{tabular}

${ }^{\mathrm{z}}$ Lettuce was harvested in the early morning using a lettuce knife at the soil level to remove the full plant along with outer whirl leaves, minus the root system (six plants per covering per high tunnel). From transplant to final harvest, fall lettuce was in the tunnel from 6 Oct. to 19 Nov. 2017 and 24 Oct. to 13 Dec. 2018. From transplant to final harvest, the spring dates were 2 Apr. 2018 to 8 May 2018 and 1 Apr. to 9 May 2019. Trial was arranged in a split-plot randomized complete block design, blocked by high tunnel with leaf colors alternating between the north and south bed of adjacent tunnels.

${ }^{\mathrm{y}}$ The following six different polyethylene (poly) film coverings were assigned within each tunnel: standard poly (standard), poly removal 2 weeks before harvest (movable), diffuse poly (diffuse), clear poly (clear), ultraviolet-A/B block poly (block), 55\% shadecloth on standard poly (shade). Parameters marked with different letters are significantly different $(P \leq 0.05)$. Tukey's honestly significant difference.

${ }^{\mathrm{x}} \mathrm{P}_{\mathrm{n}}$ was measured three times before harvest on cloudless days in the spring (30 Apr. and 5 May 2019) and fall (16 Nov. and 5 Dec. 2018). Values are three measurements to represent the replication as a whole ( $\geq$ three reps per covering). 
ones tested here found that $50 \%$ black shadecloth reduced soil temperature, canopy temperature, and yield compared with the openfield control (Li et al., 2017). Similar to our findings with tomato, increased GDD did not result in increased productivity in spring and fall lettuce trials. In previous UV exclusion studies, blocking UV-A/B resulted in greater biomass production of leaf lettuce (Adamse et al., 1997; Krizek et al., 1997, 1998). In this study, the block covering resulted in greater spring yields in the red leaf lettuce compared with shade. However, it was significantly similar in FW compared with the other coverings that allowed more UV light transmittance.

The fall temperatures, and $P A R$ and $\mathrm{P}_{\mathrm{n}}$ values were lower compared with both the summer and spring, and the marketable yield of the lettuce grown in the fall was lower than in the spring. The fall lettuce yields were likely impacted by season because of a decrease in UV radiation, $P A R$, and temperature in the fall relative to the spring (McKenzie et al., 1996; Singer et al., 2015; Wilson and Meyers, 2007). A previous study testing the same red lettuce, found that an average canopy maximin and minimum temperature of 22.1 and $13.4^{\circ} \mathrm{C}$, respectively, had an FW average of $298 \mathrm{~g} /$ plant in a 2-year study (Singer et al., 2015). The fall maximum and minimum temperatures were $\approx 5^{\circ} \mathrm{C}$ less during the fall in this study (data not shown). There was less of an effect due to covering in the fall, likely due to the reduction in available solar light. As high tunnel systems are adopted worldwide, the ability to successfully manipulate light with various coverings will be reliant on the quantity of light that is present, which is affected by seasonal fluctuation and geography (latitude and elevation).

\section{Conclusion}

High tunnels have been readily adopted by vegetable growers, and numerous studies have shown the benefit of high tunnel production with regard to season extension, yield, and quality compared with the open field. One of the challenges when conducting high tunnel research is the cost and labor requirement of these production systems and how that limits the ability to conduct replicated research. We used a custom-made high tunnel structure that allowed for true randomization within each replicate (tunnel). To our knowledge, there are no previous reports that focus on the effect of high tunnel coverings or the use of a (simulated) movable tunnel on microclimate and crop productivity. The results of this study showed that specific high tunnel coverings can be used to positively impact the microclimate and productivity of crops. Our results indicate that both solar radiation and soil temperature should be considered on a season-specific basis within the high tunnel system. Furthermore, the implementation of shadecloth should be considered carefully by high tunnel growers, as it reduced $P A R$, soil temperature, and yield in both crops. Future work that examines the use of less opaque shadecloth as well as the timing of application relevant to crop maturity would also be very valuable. During the fall, there were no effects of covering on $P_{n}$ or marketable yield, which may have been due to seasonal fluctuations in solar radiation and temperature. An important finding from this work is that the utilization of various high tunnel coverings to optimize light is reliant on the availability of solar light. This may be in contrast to greenhouse and/or indoor growing systems where supplemental lighting can be used for increased productivity and/or quality. This report was part of a larger project that addresses key questions regarding the impact of various high tunnel coverings on crop productivity, nutritional quality, and shelf life. The findings of this study are valuable for high tunnel growers who want to manipulate light within their growing system to optimize the microclimate and ultimately improve yield and other characteristics of their crops.

\section{Literature Cited}

Adamse, P., H.E. Reed, D.T. Krizek, S.J. Britz, and R.M. Mirecki. 1997. An inexpensive setup for assessing the impact of ambient solar ultraviolet radiation on seedlings. J. Nat. Resour. Life Sci. Educ. 26(2):139-144.

Agati, G. and M. Tattini. 2010. Multiple functional roles of flavonoids in photoprotection. New Phytol. 186(4):786-793, https://doi.org/10.2134/ jnrlse.1997.0139.

Altamimi, M.E. 2016. Evaluating organic and conventional management and nitrogen rate for effects on yield, soil and plant nutrient of tomato and pac choi grown under high tunnel and in the field. Kansas State Univ., Manhattan, PhD Diss. Abstr. 2097-32586. http://hdl. handle.net/2097/32586.

Becker, C., H.P. Kläring, L.W. Kroh, and A. Krumbein. 2013. Temporary reduction of radiation does not permanently reduce flavonoid glycosides and phenolic acids in red lettuce. Plant Physiol. Biochem. 72:154-160, https:// doi.org/10.1016/j.plaphy.2013.05.006.

Borrelli, K., R.T. Koenig, B.M. Jaeckel, and C.A. Miles. 2013. Yield of leafy greens in high tunnel winter production in the northwest United States. HortScience 48(2):183-188, https://doi. org/10.21273/HORTSCI.48.2.183.

Buller, T., C.L. Rivard, and K. Oxley. 2016. Growing under cover: A Kansas growers' guide. Topeka, KS: Kansas Rural Center. <https:// kansasruralcenter.org/growing-under-covera-kansas-growers-guide/>.

Bumgarner, N.R., M.A. Bennett, P.P. Ling, R.W Mullen, and M.D. Kleinhenz. 2011. Canopy cover and root-zone heating effects on fall-and spring-grown leaf lettuce yield in Ohio. HortTechnology 21(6):737-744, https://doi.org/ 10.21273/HORTTECH.21.6.737.

Bumgarner, N.R., M.A. Bennett, P.P. Ling, R.W. Mullen, and M.D. Kleinhenz. 2012. Active and passive zonal heating creates distinct microclimates and influences spring-and fall-time lettuce growth in Ohio. HortTechnology 22(2):228-236, https://doi.org/10.21273/HORTTECH.22.2.228.

Carey, E.E., L. Jett, W.J. Lamont Jr, T.T. Nennich, M.D. Orzolek, and K.A. Williams. 2009. Horticultural crop production in high tunnels in the United States: A snapshot. HortTechnology 19(1):37-43, https://doi.org/10.21273/HORTSCI.19.1.37.

Espí, E., A. Salmerón, A. Fontecha, Y. García, and A.I. Real. 2006. Plastic films and agricultural applications. J. Plast. Film Sheeting 22:85-102, https://doi.org/10.1177/8756087906064220.

Flaishman, M.A., Y. Peles, Y. Dahan, S. MiloCochavi, A. Frieman, and A. Naor. 2015. Differential response of cell-cycle and cell-expansion regulators to heat stress in apple (Malus domestica) fruitlets. Plant Sci. 233:82-94, https://doi.org/10.1016/j.plantsci.2015.01.005.

Gieske, M.F., D.L. Wyse, and B.R. Durgan. 2016. Spring-and fall-seeded radish cover-crop effects on weed management in corn. Weed Technol. 30(2):559-572, <https://www.jstor.org/stable/ $24856091>$

Gude, K.M., C.B. Rajashekar, B. Cunningham, Q. Kang, W. Wang, M. Lee, C.L. Rivard, and E. Pliakoni. 2020. Effect of high tunnel coverings on antioxidants of breaker and light red tomatoes at harvest and during ripening. Agronomy (Basel) 10(11):1639, https://doi.org/10.3390/ agronomy10111639.

Hipol, R.L. and M.L. Dionisio-Sese. 2014. Impact of light variation on the antioxidant properties of red lettuce. Electronic J. Biol. 10(2):28-34. $<$ https://ejbio.imedpub.com/impact-of-lightvariation-on-the-antioxidant-properties-ofred-lettuce.pdf $>$.

Ilić, Z.S., L. Milenković, L. Šnić, and E. Fallik. 2015. Effect of coloured shade-nets on plant leaf parameters and tomato fruit quality. J. Sci. Food Agr. 95(13):2660-2667, https://doi.org/ $10.1002 /$ jsfa. 7000 .

Janke, R.R., M.E. Altamimi, and M. Khan. 2017. The use of high tunnels to produce fruit and vegetable crops in North America. Agr. Sci. 8(7):692-715, https://doi.org/10.4236/ as.2017.87052.

Jett, L.W. 2017. High tunnels, p. 107-116. In: M.D. Orzolek (ed.). A guide to the manufacture, performance, and potential of plastics in agriculture. Elselvier, Cambridge, MA. https:// doi.org/https://doi.org/10.1016/B978-0-08-1021705.00006-3.

Krizek, D., Saftner, R., Eunhee, P., Abbott, J., Camp, M. and Clark, D. 2006. Yield data from 2005 and instrumental and sensory evaluation of tomato fruits from plants grown in high tunnels at Beltsville, Md., or obtained from commercial sources. Amer. Soc. Hort. Sci. 41(4):1083 (abstr.), https://doi.org/10.21273/ HORTSCI.41.4.1083A

Krizek, D.T., S.J. Britz, and R.M. Mirecki. 1998. Inhibitory effects of ambient levels of solar UV-A and UV-B radiation on growth of cv. New Red Fire lettuce. Physiol. Plant. 103(1):1-7, https://doi. org/10.1034/j.1399-3054.1998.1030101.x.

Krizek, D.T., R.M. Mirecki, and S.J. Britz. 1997. Inhibitory effects of ambient levels of solar UV-A and UV-B radiation on growth of cucumber. Physiol. Plant. 100(4):886-893, https://doi. org/10.1111/j.1399-3054.1997.tb00014.x.

Kumari, P., R.K. Ojha, A. Wadood, and R.P. Rajesh. 2014. Microclimatic alteration through protective cultivation and its effect on tomato yield. J. Agrometerol. 16(2):172. https://www. proquest.com/docview/1667569049/83175E82A 5BE46BDPQ/7? accountid $=28147$.

Lamont, W.J. 2009. Overview of the use of high tunnels worldwide. HortTechnology 19(1):25-29.

Lang, G.A. 2014. Growing sweet cherries under plastic covers and tunnels: Physiological aspects and practical considerations. Acta Hort. 1020:303-312, https://doi.org/10.17660/ ActaHortic.2014.1020.43.

Li, T., G. Bi, J. LeCompte, T.C. Barickman, and B.B. Evans. 2017. Effect of colored shadecloth on the quality and yield of lettuce and snapdragon. HortTechnology 27(6):860-867, https:// doi.org/10.21273/HORTTECH03809-17. 
Lorenzo, P., M.L. Garcia, M.C. Sanchez-Guerro, E. Medrano, I. Caparros, and M. Giménez. 2006. Influence of mobile shading on yield, crop transpiration and water use efficiency. Intl. Symp. Greenhouse Cooling 719:471-478, https://doi. org/10.17660/ActaHortic.2006.719.53.

Mark, U. and M. Tevini. 1996. Combination effects of UV-B radiation and temperature on sunflower (Helianthus annuus L., cv. Polstar) and maize (Zea mays L, cv. Zenit 2000) seedlings. J. Plant Physiol. 148(1-2):49-56, https:// doi.org/10.1016/S0176-1617(96)80293-8.

McKenzie, R.L., G.E. Bodeker, D.J. Keep, M. Kotkamp, and J. Evans. 1996. UV radiation in New Zealand: North-to-south differences between two sites, and relationship to other latitudes. Weather and Climate 16(1):17-26. < https://www.jstor. org/stable/44279891>.

McMaster, G.S. and W. Wilhelm. 1997. Growing degree-days: One equation, two interpretations. Agric. For. Meteorol. 87:291-300, https://doi. org/10.1016/S0168-1923(97)00027-0.

Miles, C., R. Wallace, A. Wszelaki, J. Martin, J. Cowan, T. Walters, and D. Inglis. 2012. Deterioration of potentially biodegradable alternatives to black plastic mulch in three tomato production regions. HortScience 47(9):1270-1277, https://doi.org/10.21273/HORTSCI.47.9.1270.

Moorby, J. and C.J. Graves. 1979. Root and air temperature effects on growth and yield of tomatoes and lettuce. Symp. Res. Recirculating
Water Cult. 98:29-44, https://doi.org/10.17660/ ActaHortic.1980.98.2.

O’Connell, S., C. Rivard, M.M. Peet, C. Harlow, and F. Louws. 2012. High tunnel and field production of organic heirloom tomatoes: Yield, fruit quality, disease, and microclimate. HortScience 47(9):1283-1290, https://doi.org/ 10.21273/HORTSCI.47.9.1283.

Oh, M.M., E.E. Carey, and C.B. Rajashekar. 2011. Antioxidant phytochemicals in lettuce grown in high tunnels and open field. Hort. Environ. Biotechnol. 52(2):133-139, https://doi.org/ 10.1007/s13580-011-0200-y.

Reddy, K.R. and S.K. Matcha. 2010. Quantifying nitrogen effects on castor bean (Ricinus communis L.) development, growth, and photosynthesis. Ind. Crops Prod. 31(1):185-191, https://doi.org/ 10.1016/j.indcrop.2009.10.004.

Saeed, A., K. Hayat, A.A. Khan, and S. Iqbal. 2007. Heat tolerance studies in tomato (Lycopersicon esculentum Mill.). Int. J. Agr. Biol. 9(4):649-652. https://www.fspublishers.org/.

Singer, S.M., A.E. Hamza, E.H. Abd El-Samadl, O.M. Sawan, U.A. El-Behairy, and A.F. AbouHadid. 2015. Growth, yield and mineral contents of lettuce cultivars grown in nutrient film technique (NFT) at different transplanting dates. Res. J. Pharm. Biol. Chem. Sci. 6(1):172-183, http://rjpbcs.com/pdf/2015_6(1)/[25].pdf.

Tevini, M. and A.H. Teramura. 1989. UV-B effects on terrestrial plants. Photochem. Photo- biol. 50(4):479-487, https://doi.org/10.1111/ j.1751-1097.1989.tb05552.x.

Tsormpatsidis, E., Henbest, R.G.C., Davis, F.J., Battey, N.H., Hadley, P. and Wagstaffe, A. 2008. UV irradiance as a major influence on growth, development and secondary products of commercial importance in Lollo Rosso lettuce 'Revolution' grown under polyethylene films. Environ. Expt. Bot. 63(1-3):232-239, https://doi.org/10.1016/j.envexpbot.2007.12.002.

Wallace, R.W., A.L. Wszelaki, C.A. Miles, J.S. Cowan, J. Martin, J. Roozen, B. Gundersen, and D.A. Inglis. 2012. Lettuce yield and quality when grown in high tunnel and open-field production systems under three diverse climates. HortTechnology 22(5):659-668, https:// doi.org/10.21273/HORTTECH.22.5.659.

Wilson, T.B. and Meyers, T.P. 2007. Determining vegetation indices from solar and photosynthetically active radiation fluxes. Agr. For. Meteorol. 144(3-4):160-179, https://doi.org/10.1016/ j.agrformet.2007.04.001.

Zhao, X. and E.E. Carey. 2009. Summer production of lettuce, and microclimate in high tunnel and open field plots in Kansas. HortTechnology 19(1):113-119, https://doi.org/10.21273/ HORTSCI.19.1.113.

Zhao, X., T. Iwamoto, and E.E. Carey. 2007. Antioxidant capacity of leafy vegetables as affected by high tunnel environment, fertilisation and growth stage. J. Sci. Food Agr. 87:2692-2699, https://doi.org/10.1002/jsfa.3032. 